\title{
Lipids as Markers of Induced Resistance in Wheat: A Biochemical and Molecular Approach
}

\author{
Christine Tayeh, Béatrice Randoux, Frédéric Laruelle, \\ Natacha Bourdon, Delphine Renard-Merlier and Philippe Reignault
}

Additional information is available at the end of the chapter

http://dx.doi.org/10.5772/51279

\section{Introduction}

Plant disease resistance can be defined as the ability of the plant to prevent or restrict pathogen growth and multiplication. All plants, whether they are resistant or susceptible, respond to pathogen attack by the induction of a coordinated resistance strategy. Acceleration and/or amplification of the plant responses by the application of resistance inducers could provide a biologically, environmentally and commercially viable alternative to existing pathogen control methods [1].

Among pathogenic fungi, the obligate parasite Blumeria graminis f. sp. tritici $(B g t)$ is responsible for wheat (Triticum aestivum) powdery mildew, one of the most damaging foliar diseases of this crop, especially in Northern Europe. Worldwide yield losses due to wheat powdery mildew would be about $30 \%$ without chemical treatments, so that an extensive use of conventional fungicides is undertaken. Moreover, populations of $B g t$ resistant to the main chemical fungicides (ergosterol biosynthesis inhibitors, EBIs and 2-aminopyridines) are rising, and these resistant strains emerged all over most European territories [2]. New disease management strategies based on the use of molecules that induce plant resistance via the elicitation of defence responses are therefore developed in order to reduce the use of conventional fungicides. These strategies match the growing concern about the consequences of the use of fungicides on both health and environment [3,4].

Induced partial resistance against B. graminis f.sp. tritici has been obtained in wheat with different elicitors and resistance inducers. Infection level was reduced to $57 \%$ and $58 \%$ relative to controls when nonacetylated and acetylated oligogalacturonides, respectively, were sprayed on wheat $48 \mathrm{~h}$ before inoculation with Bgt [5]. Trehalose, a non-reducing disaccharide found in a wide variety of organisms, confers a $60 \%$ protection level against 
powdery mildew [6]. It has also been shown that a double spraying of wheat plantlets with salicylic acid (SA) confers a $65 \%$ protection level against powdery mildew [7]. Prophylactic efficacies of Iodus $40 \AA$ and heptanoyl salicylic acid (HSA) against wheat powdery mildew have been tested [8]. Iodus $40 \AA$, a commercial product, is used to decrease wheat powdery mildew damage in the field. Its active ingredient is laminarin, a storage $\beta-1,3$-D-glucan (polysaccharide), extracted from the brown alga Laminaria digitata. It induces protection in grapevine against Botrytis cinerea and Plasmopara viticola [9] as well as in wheat against powdery mildew [8]. HSA is synthesized by esterification of $2-\mathrm{OH}$ benzoic acid by heptanoic acid [7]. Plantlets treated twice exhibited $60 \%$ and $100 \%$ protection levels, respectively [8]. A long up-to-run-off spraying of wheat leaves with Milsana ${ }^{\circledR}$, an ethanolic extract from leaves of the giant knotweed Reynoutria sachaliensis, $48 \mathrm{~h}$ before inoculation led to a $97 \%$ protection level against powdery mildew [10]. No direct effect against the fungus has been noticed for any of these elicitors [8] except for Milsana ${ }^{\circledR}$ which exhibited a direct fungistatic effect on B. graminis conidia germination [10]. It is now necessary to understand the mode of action and the cascade of cellular and molecular events triggered by these wheat resistance inducers.

In the last fifteen years, SA itself has been described as playing a key role in the activation of defence systems against pathogens in plants. Despite several reports [11-14], works focusing on SA as a resistance inducer are far from being as extensive as those concerning BTH, a functional analogue of SA, and, as far as we know, a single one involved wheat [8].

Plant lipids and lipid metabolic pathways have been shown to be of crucial importance during a plant-pathogen interaction. Many changes in membrane lipids are known to occur in plants at the site of infection. Moreover, lipids and lipid metabolites, released from membranes, function and act as signal molecules in the activation of plant defence responses [15].

Over the past few years, it has become increasingly clear that phosphatidic acid (PA) is involved in stress signaling because it is rapidly and transiently formed in response to various environmental stimuli [16]. PA could be generated by 2 distinct pathways as shown in figure 1: a first one involves phospholipase D (PLD) acting hydrolytically on membrane phospholipids, particularly phosphatidylcholine (PC) and phosphatidylethanolamine (PE); a second one involves phospholipase C (PLC) acting sequentially with diacylglycerol kinase (DGK) via diacylglycerol (DAG) phosphorylation [17].

Phospholipid-signaling pathways are complex, interrelated, and involve numerous enzymes and substrates [18]. As an ubiquitous enzyme family, phospholipases play various roles in stress responses [19]. Beside PLC and PLD, a main class of phospholipases A (PLA) hydrolyze phospholipids (such as PC) into the corresponding free fatty acid and lysophospholipid (such as lysoPC). Such a fatty acid can be a precursor for oxylipin biosynthesis, and lysoPC may be involved in multiple cellular processes [20]. One important finding on functions of lysoPC is that it can activate $\mathrm{H}^{+}$-ATPase in the tonoplast and cause cytoplasmic acidification, which is shown to activate defense responses and phytoalexin production [21]. The lipid messengers derived from hydrolysis of the plasma membrane are illustrated in figure 2. 


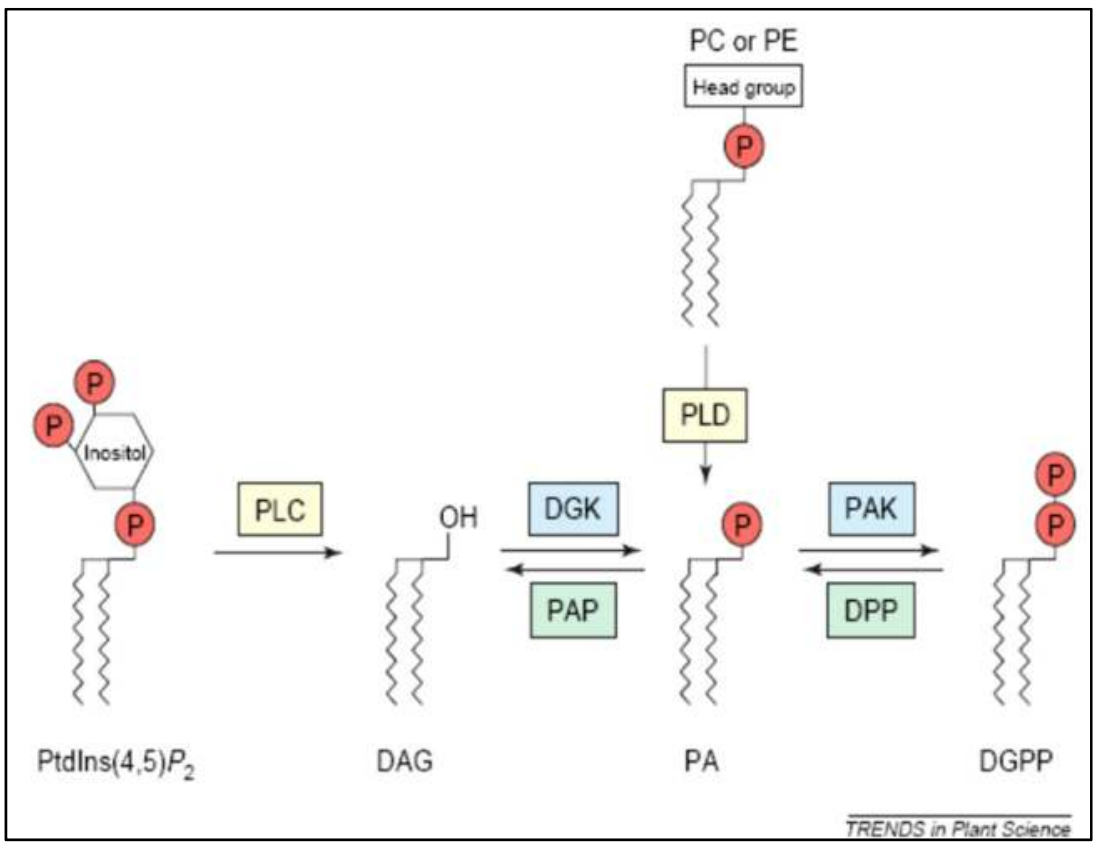

Figure 1. Formation and attenuation of phosphatidic acid (PA) [16]

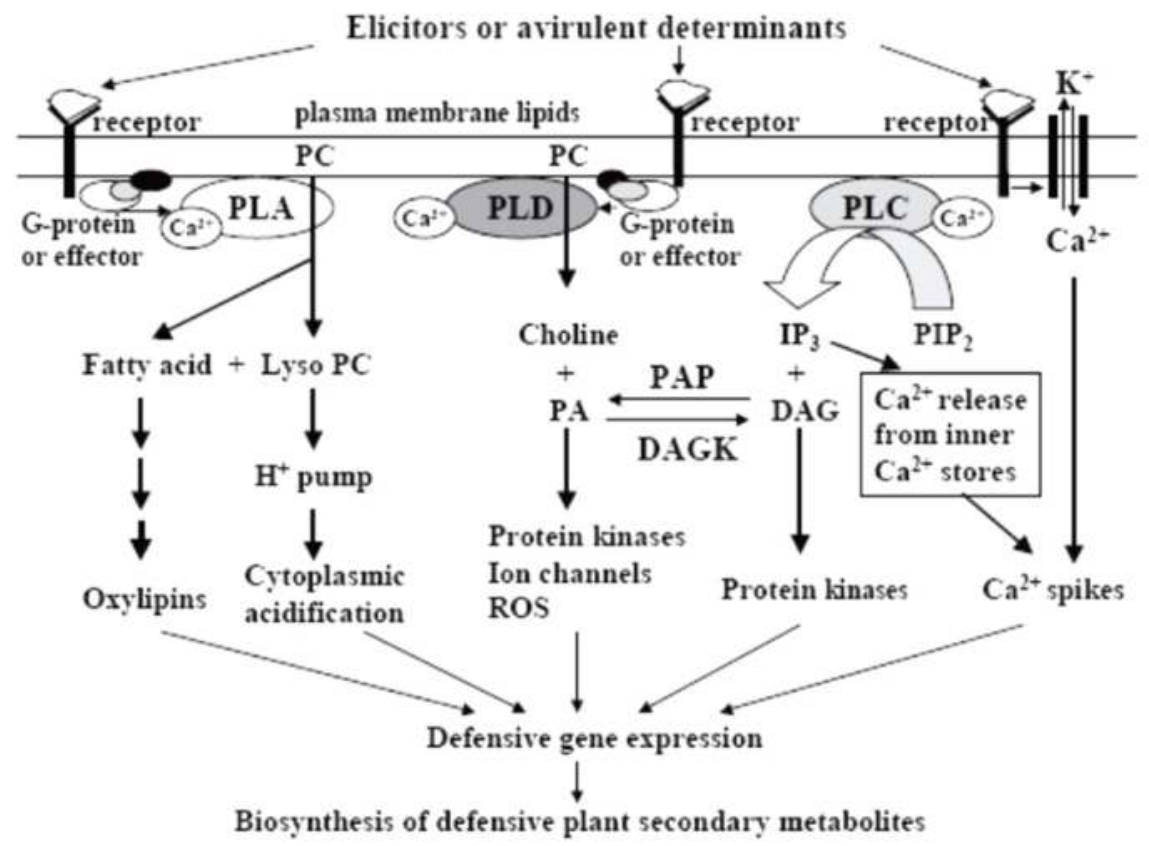

Figure 2. Lipid messengers derived from hydrolysis of plasma membrane [22] 
Adaptation of higher plants to biotic and abiotic stress is often accompanied by the occurrence of lipid peroxidation and metabolites which derived therefrom are called oxylipins. Lipid peroxydation may be the result of a coordinated action of enzymes or the result of auto-oxidation (Figure 3). Oxylipins are potent signaling molecules in the defense response in plants [23]. The synthesis of oxylipins is first catalyzed by lipoxygenases (LOXs), which add molecular oxygen to polyunsaturated fatty acids (PUFAs) to yield the corresponding fatty acid hydroperoxides that are substrates for other enzymes (figure 4) [24]. Based on their regiospecificity, the dioxygenation occurs at C-9 or C-13 and LOXs have been thus classified as 9- and 13-LOX, which yield 9- or 13-hydroperoxides, respectively [25]. In the case of linolenic acid C18:3 and 13-LOX, the resulting product is 13-HPOT (hydroperoxy octadectrienoic acid) [15]. These LOX-derived hydroperoxides can be converted through different reactions of the LOX pathway, particularly by an allene oxide synthase (AOS) leading to jasmonic acid (JA). Most of the LOX-derived compounds are considered as acting in plant defense reactions: indeed, C6 volatiles induce defense-related genes expression [26], divinyl ethers are antifungal [27], and JA is an important signaling compound that is involved in plant response to biotic stress [28,29]. Jasmonates are primarily derived from the C18:3 FA, which is released from membrane lipids via the activity of phospholipase A1.

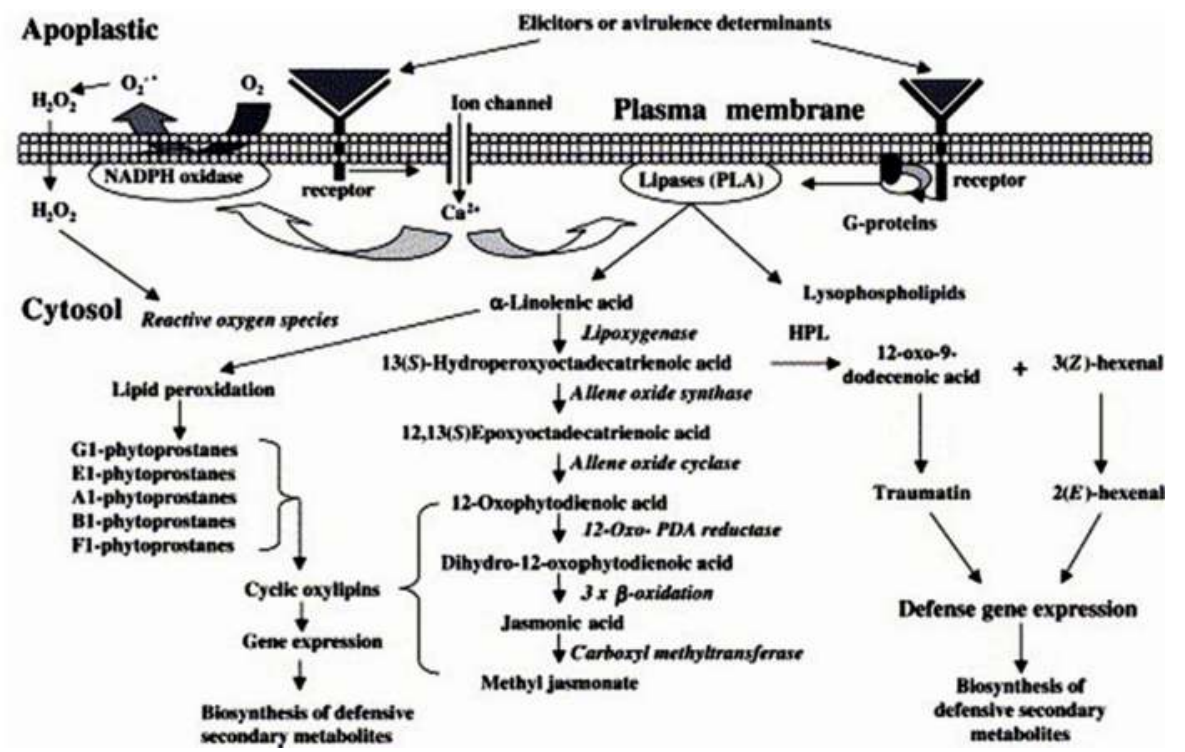

Figure 3. Schematic illustration of biosynthetic pathway of JA and other related oxylipins [22]

The phospholipase A (PLA) superfamily which catalyzes the hydrolysis of membrane phospholipids, acts up-stream the LOX to generate the corresponding PUFAs and lysophospholipids [30]. PLA may be involved in the release of free fatty acids for the biosynthesis of JA during the activation of plant defence responses. Indeed, three tobacco genes that encode putative members of the patatin family of PLAs, were identified [31]. 
Their expression is induced by microbial elicitors and upon exposure to pathogen. The high expression level of these PLA genes precedes the accumulation of JA in pathogen-inoculated or elicitor-treated tissues. Activation of PLA has also been reported in response to TMV infection in tobacco [32] and elicitor treatment of cultured parsley cells [33].

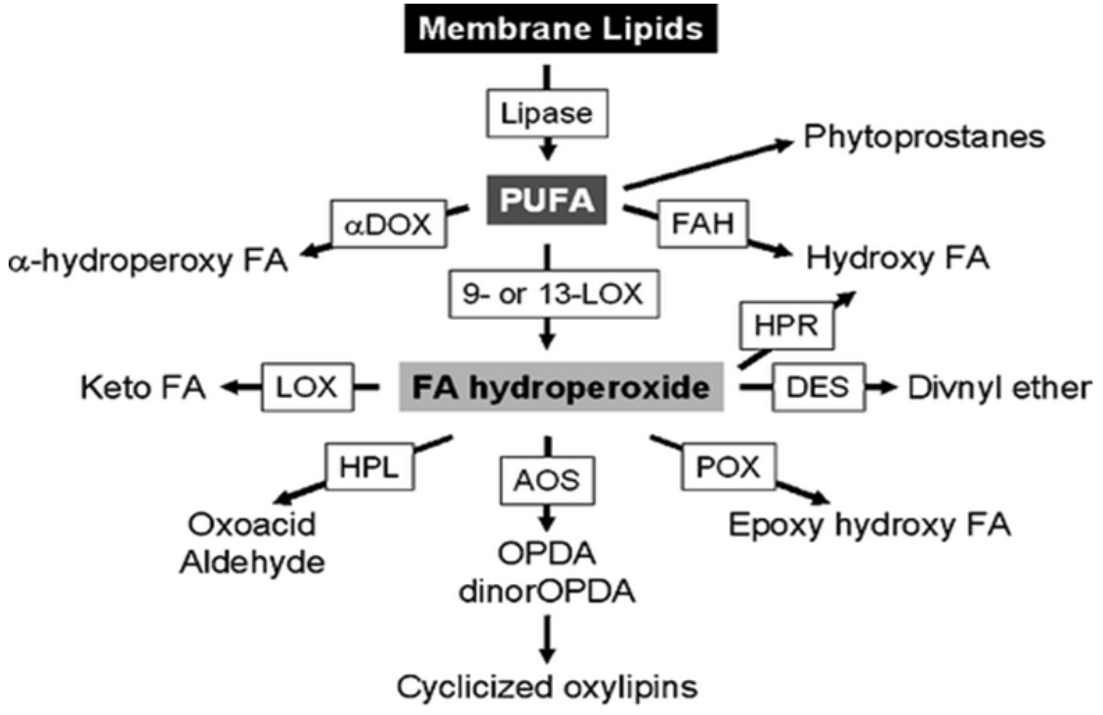

Figure 4. Enzymatic and non-enzymatic mechanisms leading to the synthesis of oxylipins in plants [15]

FAs not only serve as the major source of reserve energy but also consist of complex lipids, which are essential components of cellular membrane lipids. Increasing evidence also shows the involvement of FAs and their derivatives in signaling and altering normal and diseaserelated physiologies in microbes, insects, animals, and plants. In plants, FAs modulate a variety of responses to biotic and abiotic stresses. For instance, PUFAs levels in chloroplastic membranes affect membrane lipid fluidity and determine the plant's ability to acclimatize to temperature stress [34]. Linolenic acid (18:3) is involved in protein modifications in heatstressed plants [35]. FAs also regulate salt, drought, and heavy metal tolerance as well as wound-induced responses and defense against insect and herbivore feeding in plants [36]. FA metabolic pathways play significant roles in defense against pathogens. Classically, only passive roles were assigned to FAs in plant defense such as providing biosynthetic precursors for cuticular components (studies of FA metabolic mutants also reveal an active signaling role for the cuticle in plant defense) or JA, well known for its role in wound responses and plant defense against insect pathogens. However, recent works demonstrate more direct roles for FAs and their breakdown products in inducing various modes of plant defenses. Both 16- and 18-carbon FAs participate in defense to modulate basal, effectortriggered, and systemic immunity in plants [37].

Furthermore, lipid transfer proteins (LTPs), located in the cell wall, participate in the in vitro transfer of phospholipids between membranes and can bind acyl chains. Based on these 
properties, LTPs are thought to be involved in membrane biogenesis and regulation of intracellular FA pools [38]. Many roles were suggested for LTPs: involvement in cutin formation, embryogenesis, symbiosis and adaptation of plants to various environmental conditions [39]. Among them, defensive role of LTPs has been proposed. Indeed, LTPs have been naturally classified as members of pathogenesis-related (PR) proteins belonging to the group PR-14 [40]. Some members of this family have the ability to inhibit the growth of fungal pathogens in barley and maize [41], in sunflower against Fusarium solani [42], in transgenic rice against Magnaporthe grisea, Rhizoctonia solani and Xanthonomas oryzae [43]. In transgenic wheat expressing $A c e-A M P$, the corresponding encoded LTP showed enhanced antifungal activity against $B g t$ [44]. Ltp3F1, a novel gene encoding an antifungal protein against Alternaria sp., Curcularia lunata, Bipolaris oryzae and Sarocladium oryzae was characterized from wheat [45].

In this review, we will discuss further and extend the study conducted by Renard-Merlier et al. [46], where a global investigation of total FA content in relation to treatment with four inducers of resistance and to powdery mildew infection was undertaken. Previous studies established that lipid metabolism is altered by Milsana ${ }^{\circledR}$, Iodus $40 \AA$, HSA, SA and trehalose $[8,10]$; therefore, our work aimed to characterize their impact at the total FA level. During a time course experiment, content (quantitative analysis) and percentage (qualitative analysis) of FAs were compared in treated plants and in controls, as well as in non-inoculated (ni) plants and Bgt-challenged plants (i). Previous results will be considered and discussed relatively to new findings.

Moreover, the effect of one resistance inducer, namely SA, on lipid metabolism is evaluated by molecular and biochemical approaches.

Phospholipids being the major membrane components, we investigated PC, PE, DAG and PA content variation in wheat leaves infiltrated with salicylic acid (SA). SA can modulate the content variation of these compounds, reservoirs from which biologically active lipids and precursors of oxidized lipids are released.

At the transcriptional level, a PLC-encoding gene expression was investigated in an attempt to assign any participation of this pathway in the phospholipids equilibrium described above.

We also investigated free FAs and PLFAs content variations in SA-infiltrated wheat leaves; this pool of lipids is quite interesting since it ensures several functions, from being an energy source to acting as cellular messengers; the latter being highly related to resistance induction in plants. The lipoxygenase response to SA-infiltration, at the molecular and enzymatic level, was also evaluated; this enzyme activity is important for oxylipins biosynthesis in plants, because of its position upstream the cascade of enzymatic lipid peroxydation.

An LTP-encoding gene expression was also monitored, taking into account the possible antifungal activity of LTPs as well as their ability to bind and transport membrane lipids, thus participating in lipid-mediated signaling mechanisms. 


\section{Material and methods}

\subsection{Treatments application}

Wheat (Triticum aestivum) cultivar Orvantis was used throughout the experiments. It was provided by Benoit C.C. (Orgerus, France). This cultivar is fully susceptible to the MPEBgt1 powdery mildew isolate. First leaf of ten-day-old wheat plantlets was infiltrated with salicylic acid $(1 \mathrm{~g} / \mathrm{L})$ solution using a hypodermic syringe without needle. Infiltrated area was delineated with a marker pen. Control plantlets were infiltrated with distillated water.

Ten-day-old wheat seedlings were treated with solutions of Iodus $40 \AA(1 \mathrm{~g} / \mathrm{L}), \mathrm{HSA}(1 \mathrm{~g} / \mathrm{L})$, Milsana ${ }^{\circledR}(0.3 \% \mathrm{v} / \mathrm{v})$ and trehalose $(15 \mathrm{~g} / \mathrm{L})$ as described by Renard-Merlier et al. [46]. Treatments consisted in "up-to-run-off" sprayings. Two days after inducer treatments, seedlings to be inoculated were sprayed with conidia of Bgt suspended in Fluorinert FC43 at a concentration of $5.10^{6}$ spores. $\mathrm{mL}^{-1}$.

\subsection{RNA extraction and quantification of gene expression by real-time PCR}

SA and water-infiltrated wheat leaves were sampled at 3, 6, 9, 12, 15, 18, 21, 24, 48, 72 and 96 hours after infiltration (hai) and stored at $-80^{\circ} \mathrm{C}$ until use. Total RNA was extracted from 100 mg plant tissue using RNeasy Plant Mini Kit (Quiagen, The Netherlands) with some modifications of the protocol. cDNA synthesis was carried out using High Capacity cDNA Reverse Transcription Kit (Applied Biosystems, USA) according to the manufacturer's protocol. Real Time qPCR was performed using ABI Prism 7300 detection system (Applied Biosystems, USA). The $t u b$ and ef $1 \alpha$ genes, encoding respectively for tubulin and elongation factor ef1alpha, were used as reference genes. The relative expression of the target genes was evaluated in SA-infiltrated wheat leaves compared with water-infiltrated leaves and normalized to the $t u b$ and ef1 $a$ expression level. The analyses were performed using the relative expression software tool REST® as described in [47]. The experiments were repeated twice with similar results and representative results are presented.

\subsection{LOX assay}

LOX was assayed as described in [10] according to [48] and [49] with slight modifications. The results are the mean of three biological repetitions.

\subsection{Fatty acid extraction and analysis}

Total cellular FAs extraction and purification were performed by the authors in [46] using adapted protocols from [50]. The results are means of three independent repetitions.

Free FAs, PLFA and PL extraction was carried out according to the method described in [51]. Data shown are the results of the first experiment, which need to be confirmed by a biological repetition. 


\section{Results and discussion}

\subsection{PA content increases after $S A$ infiltration}

Because of its central position in the pathways mentioned above, the first results presented here have been obtained for PA. Table 1 shows the variations in PA levels in SA-infiltrated leaves, compared to the control. No change in PA content was observed during the first 24 hours after infiltration (hai) of SA, compared to the water-infiltrated wheat leaves; even though a slight accumulation of PA was observed in water-infiltrated leaves in comparison to the untreated plants, probably due to the stress generated by the infiltration. However, SA induced increases in PA content from $24 \mathrm{~h}$ till 96 hai, with a maximum of 6.2-fold increase at 72 hai.

Time after SA infiltration

\begin{tabular}{ccccc}
\hline & $24 \mathrm{~h}$ & $48 \mathrm{~h}$ & $72 \mathrm{~h}$ & $96 \mathrm{~h}$ \\
\hline \multirow{2}{*}{ PA content } & $\begin{array}{l}\text { 2.2-fold } \\
\text { increase }\end{array}$ & 2.7-fold increase & 6.2-fold increase & 1.19-fold increase \\
\hline
\end{tabular}

Table 1. Variations in PA levels in SA-infiltrated wheat leaves compared to the water-infiltrated control

These results confirm some variations in PA content reported by several authors. Treatment of $A$. thaliana protoplasts with $\mathrm{H}_{2} \mathrm{O}_{2}$ increases PA content by $30 \%$ [52]. Furthermore, elicitors from plant pathogens activate the PLC-DGK pathway, which consisted of a rapid accumulation of PA within 2 minutes in transgenic tobacco cells treated with the race-specific elicitor Avr4 [53]. A transient accumulation of PA was also recorded in suspension-cultured tomato cells treated with the general elicitors $\mathrm{N}, \mathrm{N}$ ',N",N'"-tetraacetyl-chitotetraose, xylanase, and the flagellin-derived peptide flg22 [54]. In rice cells, the PA amount increased rapidly after treatment with $\mathrm{N}$ acetylchitooligosaccharide elicitor [55]. Moreover, the PA increase is likely to occur upstream of the oxidative burst [53,55]. Furthermore, method of PA assessment. Furthermore, all these studies point out the rapid accumulation of PA upon treatments, generally within minutes. According to [16], signaling lipids, unlike structural lipids, are present only in minute amounts, yet their levels increase rapidly in response to certain stimuli. Such an accumulation is transient because the signal is rapidly down regulated. However, none of these characteristics, namely the rapid and transient accumulation upon treatment, met our results. SA induces a PA accumulation that occurred not earlier than $24 \mathrm{~h}$ after SA infiltration and seemed to last for at least 4 days. This result, that does not match the general trend, may be explained by a late induction of one or both of the phospholipases pathways leading to PA formation. Since the magnitude of PA change varies upon the treatment, tissue and method of PA assessment [17], our findings could be attributed to the treatment and/or to the tissue nature - infiltration of SA and PA assessment in planta - whereas most of the studies are conducted on cellular cultures. 


\subsection{PLC gene expression is up-regulated and DAG content increases in SA- infiltrated leaves}

In order to corroborate the PA formation with the PLC-DGK pathway activation, the expression of the PLC gene, encoding a phospholipase $\mathrm{C}$, was measured over the timecourse experiment, compared to the water-infiltrated wheat leaves, and normalized to two reference genes, $t u b$ and ef1 $\alpha$, encoding tubulin and elongation factor, respectively (Figure 5). The expression pattern of the PLC gene consisted of three up-regulations: 3.5 and 4.8 -fold increases were induced at 9 and 21 hai, respectively. Furthermore, this gene expression was strongly increased from 48 till 96 hai, with an average of 9-fold increase over this period. This late high up-regulation of PLC gene correlates with the late PA detection in wheat leaves between 48 and $96 \mathrm{~h}$ after SA infiltration. The accumulation of PA is probably due to this pathway's stimulation after PLC gene's expression and synthesis of the corresponding enzyme.

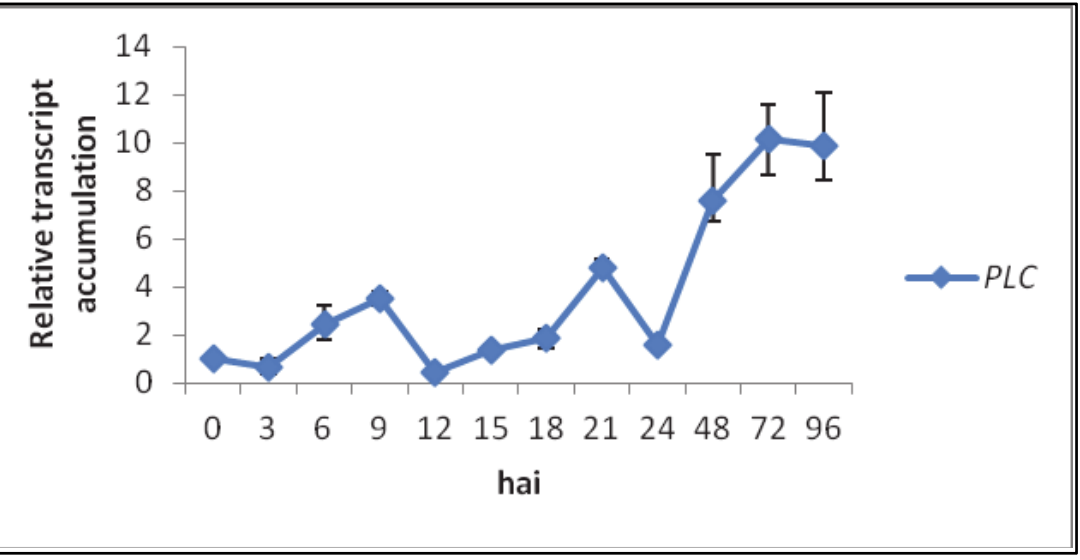

Figure 5. PLC gene expression in wheat leaves infiltrated with SA

PA formation through the phospholipase $C$ pathway results from two enzymes acting sequentially: PLC hydrolyses phosphatidylinositol-4,5-bisphosphate [PtdIns $(4,5) \mathrm{P} 2$, also abbreviated as PIP2] into inositol-1,4,5-trisphosphate [Ins(1,4,5)P3] and DAG. DAG remains in the membrane and is rapidly phosphorylated to PA by DGK (Figure 1). The variation in DAG levels in SA-infiltrated wheat leaves is presented in table 2. During the first $24 \mathrm{~h}$ after SA infiltration, no clear variation pattern in DAG content was observed. However, SA induced the accumulation of DAG from 24 till 96 hai, with a maximum of 2.18-fold increase at 72hai. Interestingly, DAG accumulation, as well as PLC gene expression, was recorded in the same period of the time-course experiment, 24 till $96 \mathrm{~h}$ after SA infiltration. The DAG accumulation seems to be the consequence of the induction of PLC gene expression.

Twenty four hours after infiltration, SA induces the expression of PLC-encoding gene, simultaneously with an accumulation of DAG and PA. One could think that DAG content must decrease in order to fulfill PA formation; indeed, the contribution of DAG could only 
be confirmed by the investigation of DGK activity. Even if the subsequent enzymatic conversion of DAG doesn't lead to PA formation, one must keep in mind that the hydrolysis of PtdIns $(4,5) \mathrm{P}_{2}$ into Ins $(1,4,5) \mathrm{P}_{3}$ is of a great interest since the latter diffuses into the cytosol where it possibly triggers calcium flux/release from intracellular stores [20].

In addition, the simultaneous increase of these compounds could be due to the durable PLC gene expression, ensuring a continuous supply of DAG to be phosphorylated to PA.

\begin{tabular}{|c|c|c|c|c|c|c|c|}
\hline & \multicolumn{7}{|c|}{ Time after SA infiltration } \\
\hline & $6 \mathrm{~h}$ & $12 \mathrm{~h}$ & $18 \mathrm{~h}$ & $24 \mathrm{~h}$ & $48 \mathrm{~h}$ & $72 \mathrm{~h}$ & $96 h$ \\
\hline DAG content & $\begin{array}{l}\text { 1.1-fold } \\
\text { increase }\end{array}$ & $\begin{array}{c}\text { 1.1-fold } \\
\text { decrease }\end{array}$ & $\varnothing$ & $\begin{array}{l}1.26 \text {-fold } \\
\text { increase }\end{array}$ & $\begin{array}{l}\text { 1.62-fold } \\
\text { increase }\end{array}$ & $\begin{array}{l}\text { 2.18-fold } \\
\text { increase }\end{array}$ & $\begin{array}{l}\text { 1.56-fold } \\
\text { increase }\end{array}$ \\
\hline
\end{tabular}

Table 2. Variation in DAG level in SA-infiltrated wheat leaves compared to the control

\subsection{PE and PC contents vary in SA-infiltrated leaves}

PA could also be generated by the phospholipase D pathway which hydrolyzes structural membrane phospholipids such as PE and PC (Figure 1). The variations of PE and PC levels in SA-infiltrated leaves compared to the control are presented in table 3. While accumulation of PC was observed during the whole time-course experiment (except for 24 and 96 hai), PE accumulated the first $18 \mathrm{~h}$ after treatment. Afterward, SA induced a decrease in the PE content between 24 and 96 hai, with a maximum decrease at 48 and 72 hai. These results match the increased PA level in SA-infiltrated wheat leaves in the same period, suggesting that this pathway is involved in PA formation. Since PC level was maintained and even increased, this phospholipid doesn't seem to be involved in PA production, under SA treatment. The PE/PC ratio is also reduced from 48 till 96 hai. Substantial alterations in the lipid composition of plasma membrane are a widely known process to stress adaptation, such as water deficit: the PC/PE ratio changed from 1.1 in plants non-acclimated to water stress to 0.69 in acclimated ones [56].

\begin{tabular}{|c|c|c|c|c|c|c|c|}
\hline \multicolumn{8}{|c|}{ Time after SA infiltration } \\
\hline & $6 \mathrm{~h}$ & $12 \mathrm{~h}$ & $18 \mathrm{~h}$ & $24 \mathrm{~h}$ & $48 \mathrm{~h}$ & $72 \mathrm{~h}$ & $96 \mathrm{~h}$ \\
\hline $\begin{array}{l}\text { PE } \\
\text { content }\end{array}$ & $\begin{array}{l}\text { 1.4-fold } \\
\text { increase }\end{array}$ & $\begin{array}{l}\text { 1.3-fold } \\
\text { increase }\end{array}$ & $\varnothing$ & $\begin{array}{l}\text { 1.3-fold } \\
\text { decrease }\end{array}$ & $\begin{array}{l}\text { 6.6-fold } \\
\text { decrease }\end{array}$ & $\begin{array}{l}\text { 6.2-fold } \\
\text { decrease }\end{array}$ & $\begin{array}{l}\text { 2.3-fold } \\
\text { decrease }\end{array}$ \\
\hline $\begin{array}{l}\text { PC } \\
\text { content }\end{array}$ & $\begin{array}{l}\text { 1.4-fold } \\
\text { increase }\end{array}$ & $\begin{array}{l}\text { 2.9-fold } \\
\text { increase }\end{array}$ & $\begin{array}{l}\text { 3.8-fold } \\
\text { increase }\end{array}$ & $\varnothing$ & $\begin{array}{l}\text { 1.8-fold } \\
\text { increase }\end{array}$ & $\begin{array}{l}\text { 1.4-fold } \\
\text { increase }\end{array}$ & $\varnothing$ \\
\hline $\mathrm{PE} / \mathrm{PC}$ & 2 & 1.2 & 1.2 & 2.2 & 0.2 & 0.5 & 0.6 \\
\hline
\end{tabular}

Table 3. Variations in PE and PC levels (compared to the control) and PE/PC ratio induced in SAinfiltrated wheat leaves

In conclusion, SA seems to induce the formation of PA through the activation of phospholipases C and/or D pathways. In Arabidopsis, PLC signaling is involved in some 
responses mediated by ABA without any contribution of DGK activity or PA [57]. This signaling, via $\operatorname{Ins}(1,4,5) \mathrm{P} 3$, is also reported as an early response to salinity and hyperosmotic stress [58,59]. The PLC-DGK pathway was sought in Arabidopsis after cold exposure [60], in transgenic tobacco cells upstream the oxidative burst as in [53] and after contact with pathogens. In suspension-cultured alfalfa cells, the nod factor activates this pathway [61].

Treatment of tomato cell cultures with the fungal elicitor xylanase resulted in a rapid and dose-dependent nitric oxide (NO) accumulation, required for PA production via the activation of PLC-DGK pathway. PA and, correspondingly, xylanase were shown to induce ROS production [62].

The PLD pathway is involved in every mentioned stress signaling, except cold-induced stress. Several Arabidopsis PLDs were found to be induced in response to Pseudomonas infection [63]. The PLD pathway contribution was also found in Arabidopsis upon drought [64], ethylene treatment [65], freezing [66] and wounding [67,68].

Moreover, signaling lipids can affect the activity of target enzymes. In [69], the authors showed an activation of a calcium-dependent protein kinase DcCPK1 by PA in Daucus carota. In Arabidopsis, the activation of AtPDK1, a protein kinase, target of PLD-generated $\mathrm{PA}$, is involved in root hair growth [70]; the PLD-derived PA also interacts with ABI1 phosphatase and regulates ABA signaling [71].

All together, these results are the first evidence for SA as an inducer of PA formation in wheat leaves. Increases in PA levels in SA-treated wheat leaves seem to be highly related to the induction of plant genes encoding phospholipases that are involved in the synthesis or release of PA.

\section{4. $L O X$ gene expression and LOX activity are enhanced upon SA-infiltration}

In the present experiments, the lox gene expression showed a 12 and 14 -fold increase at 9 and 21 hai respectively, in SA-infiltrated leaves. This gene expression was also strongly induced later, with a 166 and 156-fold increase at 48 and 96 hai respectively (Figure 6).

In grapevine plantlets, rhamnolipids induced for lox gene expression a 7-fold increase $24 \mathrm{~h}$ after immersion in the rhamnolipids solution [72]. In wheat, transcripts of WCI-2 (Wheat Chemically Induced gene) gene, which encodes a lipoxygenase, accumulated quickly in response to MeJA, SA and BTH treatments (from $2 \mathrm{~h}$ to $24 \mathrm{~h}$ for MeJA, and from $4 \mathrm{~h}$ and to 20 $\mathrm{h}$ for the other elicitors); however, SA induced this gene's expression to a lesser extent than the other two compounds [73]. The contribution of SA to early signaling events by the stimulation of lipoxygenase-encoding genes is therefore established. Nevertheless, the authors didn't record any accumulation of the transcripts of WCI-2 gene the first $24 \mathrm{~h}$ after wheat seedlings inoculation with $B g t$ nor $B g h$ (incompatible interaction). However, accumulation of these transcripts was found in latter stages of wheat infection with powdery mildew. In infectious conditions, the lox gene seemed to be expressed quite late [74]. Infiltration with SA reproduced a similar lox-encoding transcripts profile with a late up-regulation of the lox gene to a 166 and 156-fold increase at 48 and 96 hai, respectively. 


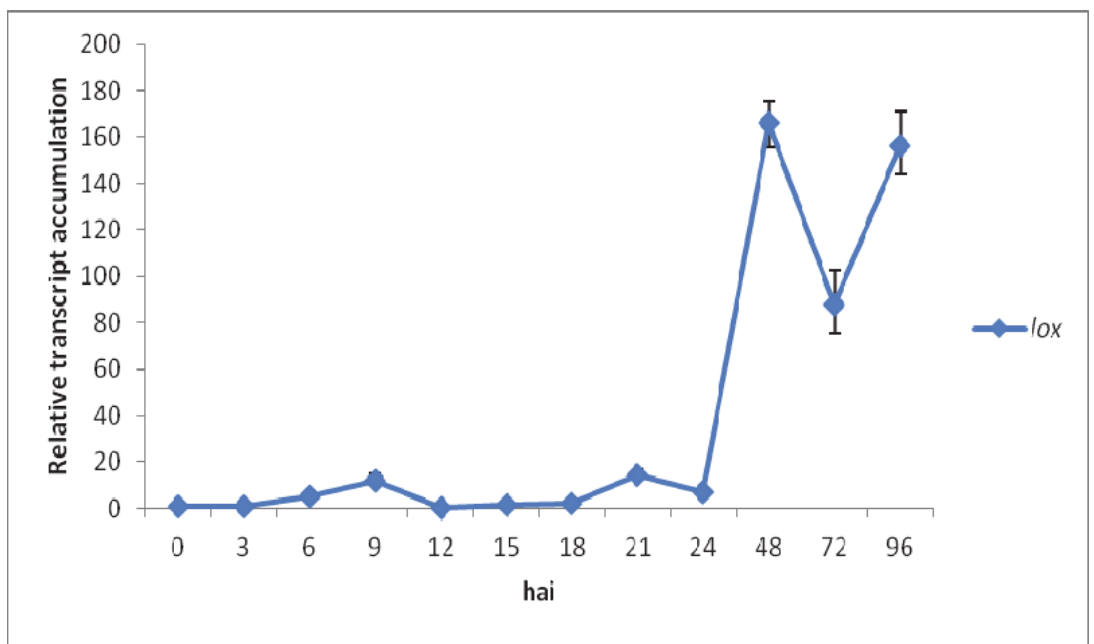

Figure 6. lox gene expression in wheat leaves treated with SA

Figure 7 shows the LOX activity in leaf extracts at 6, 12, 18, 24, 48, 72 and $96 \mathrm{~h}$ after SA infiltration in comparison to water-infiltrated leaves. During the first $48 \mathrm{~h}$, the LOX activity was decreased in SA-infiltrated leaves. However, SA induced significant 1.7 and 3.8-fold increases in LOX activity at $72 \mathrm{~h}$ and $96 \mathrm{hai}$, compared to the control.

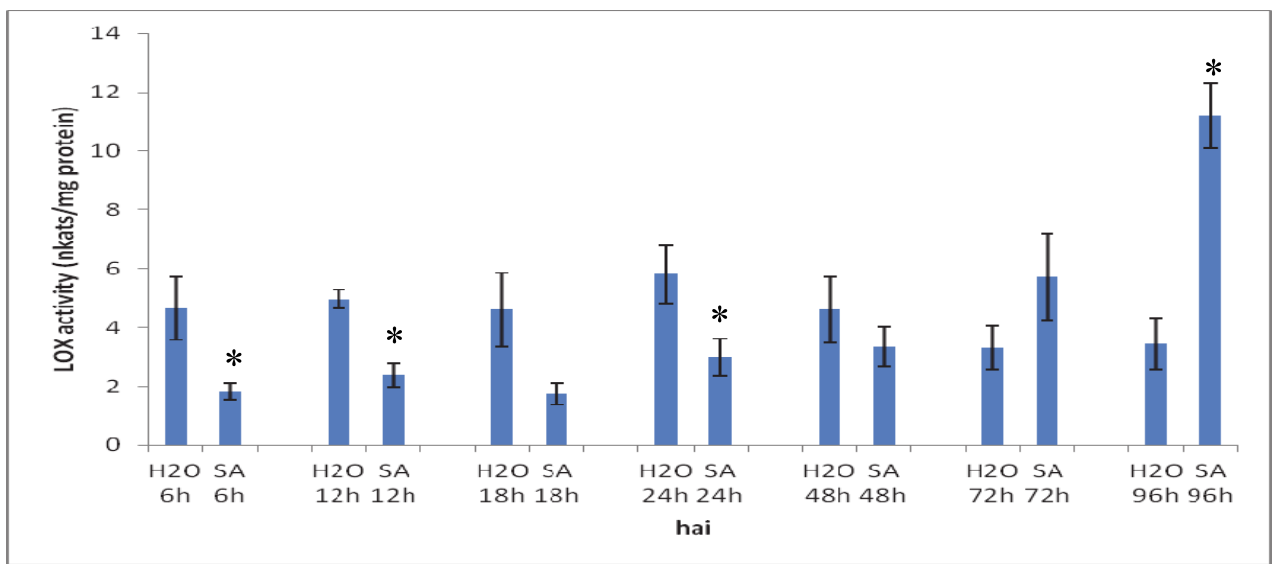

Figure 7. Time-course activity of LOX in water and SA-infiltrated wheat leaves. Data represent means of 3 independent experiments. Bars with an asterix are different from water control plantlets as determined by ANOVA followed by a multiple range test (LSD) $(\mathrm{P}<0.05)$.

When compared together, profiles of lox gene expression and LOX activity in SA-infiltrated leaves show interestingly that the first lox up-regulations, $24 \mathrm{~h}$ after SA infiltration, are not followed by the corresponding enzymatic activity. Induction of LOX activity by SA was only detectable after lox transcripts accumulation was the most important, between 48 and 96hai. 
In non-infectious context, the induction of a LOX activity was also assessed in wheat by Renard-Merlier et al. [8]. Wheat sprayings with HSA enhanced a 1.5-fold increase in LOX activity, compared to corresponding ethanol control, only $96 \mathrm{~h}$ after treatment. Thus, infiltration of SA as well as HSA sprayings induced similar LOX enzymatic activity profile. However, these authors didn't report any significant difference in LOX activity between control and SA-sprayed leaves over the 4 days after treatment. This finding highlights the effect of SA functionalization, probably improving the penetration of HSA through the hydrophobic plant cuticle. Moreover, HSA, which increased the protection level against $B g t$ from $50 \%$ in SA-treated wheat leaves to $95 \%$, induced an 8 -fold increase of the LOX activity in inoculated conditions.

LOX-derived products such as hydroperoxy, hydroxyl and keto fatty acids accumulate in plants in response to attack by pathogens and treatment with inducers of plant defence responses [75]. For example, in A. thaliana, infection by $P$. syringae causes accumulation of ketodienoic fatty acids in $A$. leaves as well as the cell death and induces expression of the GST1 gene, which encodes a glutathione-S-transferase [76]. In another study, SA treatment was shown to cause the accumulation of 13 (S)-hydroxyoctadecatrienoic acid (13-HOTrE) in barley leaves, and application of 13-HOTrE induces the expression of the PR1B gene, suggesting the involvement of 13-HOTrE in SA signaling in barley [77]. One must keep in mind that the primary products of PUFAs enzymatic oxidation are often converted to oxylipins such as JA. In barley leaves, 13-HOD and 13-HOT (hydroxyl PUFAs after reductase on HPOD and HPOT respectively) accumulated suggesting that the reductase branch of the LOX pathway is the object of preferential induction upon SA treatment, among the various metabolic transformations of the LOX-derived 13-HPOT or 13-HPOD. No accumulation of other LOX pathway-products was observed. SA as well as 13-HOT induced PR1 gene expression, $48 \mathrm{~h}$ after treatment. In barley leaves, at least one specific LOX is transcriptionnaly activated by SA and JA. This LOX-100 is a 13-LOX located in the chloroplast. However, this LOX-100 gene was not expressed upon infection with powdery mildew in susceptible and non-susceptible barley lines [78]. The co-induction of LOX and PR1 by SA suggests a role in plant defense reaction.

\subsection{FAs content varies in resistance inducers-treated wheat plants}

\subsubsection{Total FAs content vary in trehalose, Iodus40, Milsana and HSA-treated wheat leaves}

In wheat, Renard-Merlier et al. [46] conducted a global investigation of total FA content in relation to treatment with four inducers of resistance and to powdery mildew infection.

Table 4 presents a summary of the observed variations of several FAs content at the quantitative and qualitative levels induced by the four tested resistance inducers and these results are now discussed on the basis of the most recent literature as well as our results presented above. 


\begin{tabular}{|c|c|c|c|c|c|c|c|c|}
\hline & \multicolumn{2}{|c|}{$\mathrm{C} 12: 0$} & \multicolumn{2}{|c|}{ C18:1 } & \multicolumn{2}{|c|}{$18: 2$} & \multicolumn{2}{|c|}{$\mathrm{C} 20: 2$} \\
\hline & quantitative & qualitative & quantitative & qualitative & quantitative & qualitative & quantitative & qualitative \\
\hline \multicolumn{9}{|c|}{ Trehalose } \\
\hline ni & $\varnothing$ & $\varnothing$ & $\varnothing$ & $\varnothing$ & $\varnothing$ & $\varnothing$ & $\varnothing$ & $\varnothing$ \\
\hline i & $\begin{array}{l}\text { 4.0-fold } \\
\text { increase }\end{array}$ & $\begin{array}{l}\text { 2.4-fold } \\
\text { increase }\end{array}$ & $\varnothing$ & $\varnothing$ & $\varnothing$ & $\varnothing$ & $\varnothing$ & $\begin{array}{l}\text { 1.3-fold } \\
\text { decrease }\end{array}$ \\
\hline \multicolumn{9}{|c|}{ Iodus 40} \\
\hline ni & $\varnothing$ & $\varnothing$ & $\begin{array}{l}1.2 \text {-fold } \\
\text { increase }\end{array}$ & $\begin{array}{l}2.2 \text {-fold } \\
\text { increase }\end{array}$ & $\varnothing$ & $\varnothing$ & $\begin{array}{l}1.5 \text {-fold } \\
\text { decrease }\end{array}$ & $\begin{array}{l}1.33 \text {-fold } \\
\text { decrease }\end{array}$ \\
\hline $\mathrm{i}$ & $\begin{array}{l}2.8 \text {-fold } \\
\text { increase }\end{array}$ & $\begin{array}{l}1.5 \text {-fold } \\
\text { increase }\end{array}$ & $\varnothing$ & $\varnothing$ & $\varnothing$ & $\varnothing$ & $\varnothing$ & $\varnothing$ \\
\hline \multicolumn{9}{|c|}{ Milsana } \\
\hline ni & $\varnothing$ & $\varnothing$ & $\varnothing$ & $\varnothing$ & $\varnothing$ & $\varnothing$ & $\begin{array}{l}\text { 2.3-fold } \\
\text { decrease }\end{array}$ & $\varnothing$ \\
\hline $\mathrm{i}$ & $\begin{array}{c}4.8 \text {-fold } \\
\text { increase }\end{array}$ & $\begin{array}{l}1.5 \text {-fold } \\
\text { increase }\end{array}$ & $\varnothing$ & $\varnothing$ & $\varnothing$ & $\varnothing$ & $\begin{array}{c}1.8 \text {-fold } \\
\text { decrease }\end{array}$ & $\begin{array}{c}2.0 \text {-fold } \\
\text { decrease }\end{array}$ \\
\hline \multicolumn{9}{|c|}{ HSA } \\
\hline ni & $\varnothing$ & $\varnothing$ & $\varnothing$ & $\varnothing$ & $\varnothing$ & $\begin{array}{l}\text { 1.15-fold } \\
\text { increase }\end{array}$ & $\varnothing$ & $\varnothing$ \\
\hline $\mathrm{i}$ & $\varnothing$ & $\varnothing$ & $\varnothing$ & $\varnothing$ & $\begin{array}{l}\text { 1.6-fold } \\
\text { increase }\end{array}$ & $\begin{array}{l}\text { 1.15-fold } \\
\text { increase }\end{array}$ & $\varnothing$ & $\varnothing$ \\
\hline
\end{tabular}

Table 4. Summary of variations observed in C12:0, C18:1, C18:2 and C20:2 content at the quantitative ( $\mu$ g.mg ${ }^{-1}$ dry weight) and qualitative (percentage of total FAs) levels induced by inoculation, trehalose, Iodus $40 ®$, Milsana ${ }^{\circledR}$ or HSA sprayings. These variations are observed 4 days after sprayings in non inoculated (ni) plants and 2 days post inoculation in inoculated (i) conditions

Lauric acid (C12:0) content quantitatively increased after Iodus 40® (2.8-fold), Milsana ${ }^{\circledR}$ (4.8-fold) and trehalose (4-fold) treatment in (i) plants (2 days after inoculation). In [79], the authors showed that Vicia sativa seedlings treated with MeJA exhibit an increase in lauric acid $\omega$-hydroxylase activity, an enzyme that converts $\mathrm{C} 12: 0$ into hydroxylated forms potentially involved in cutin monomer synthesis. Moreover, C12:0 itself has several relevant biological properties such as antifungal, antiviral, antiparasite and antibacterial activities [80,81]. However, none of the four compounds induced any variation in C12:0 level in noninfectious conditions. Since no elicitation was observed in this context, priming effect on C12:0 accumulations could be proposed for these resistance inducers in wheat against Bgt.

Contents of C20:2 (eicosadienoic acid) decreased in Iodus 40®- and Milsana ${ }^{\circledR}$-treated (ni) plants compared to the corresponding controls (4 days after treatment). The decrease was confirmed at the qualitative level only for Iodus $40 \AA$. In (i) conditions, only Milsana ${ }^{\circledR}$ induced a significant decrease in C20:2 content at both levels whereas TR induced a decrease perceptible at the qualitative level only. In (i) plants, C20:2 increased (data not shown). C20:2 content seemed to be affected by fungal infection of the plant to a greater extent than by any of the resistance inducing treatments, since similar quantities were found in watercontrol (i) plants as well as in resistance inducers-treated plants. The link between C20:2 and infection was also reported in [82].Transgenic A. thaliana plants producing C20:2 exhibited 
enhanced resistance to the aphid Myzus persicae, the fungal pathogen Botrytis cinerea and to the oomycete pathogen Phytophtora capsici.

C18:1 (oleic acid) in Iodus 40®-treated (ni) plants showed a quantitative 1.2 fold-increase. C18:1, as well as other C18 and C16 FAs, are well known substrates for cutin monomer synthesis [83]. One could suggest that Iodus $40 \AA$, by stimulating the accumulation of this FA, contributes to the reinforcement of the plant cuticule prior to fungal contamination. In cultured parsley cells, a biphasic time-course for C18:1 increase was obtained upon treatment with peptidic or fungal elicitors [84]. In [85], the authors suggested that chloroplastic C18:1 level is critical for normal pathogen defense responses in Arabidopsis, including programmed cell death and systemic acquired resistance (SAR). In [86], it was shown that the oleic acid-mediated pathway induces constitutive defense signaling and enhances resistance to multiple pathogens in soybean. C18:1 and linoleic (18:2) acid levels, in part, regulate fungal development, seed colonization, and mycotoxin production by Aspergillus spp. [87]. Direct antifungal activity has also been reported for C18:1, since it inhibits, in a dose-dependent manner, the germination of Erysiphe polygoni spores [88].

The amount of C18:2 increased (1.6-fold) 4 days after HSA treatment in (i) plants. For C18:2, the accumulation in sorbitol-treated barley leaves was reported from $12 \mathrm{~h}$ till $72 \mathrm{~h}$ after treatment [89]. Cold acclimating potato was found to accumulate linoleic acid (18:2) in the membrane glycerolipids of the leaves [90]. C18:2 is also a substrate for cutin monomer synthesis and can therefore contribute to cuticle reinforcement.

Among the four inducers tested, Iodus $40 \AA$ had the largest effects on FA levels, since it increased C12:0 and C18:1 and decreased C20:2. This product, which active ingredient is laminarin (polysaccharide), induced decreases in lipid peroxydation level all over the timecourse experiment [8].

Trehalose and Milsana ${ }^{\circledR}$ had similar effects on FAs profile with induced increases in C12:0 and decreases in C20:2 contents. However, TR and Milsana ${ }^{\circledR}$ modes of action are quite different in the wheat-powdery mildew interaction. TR activates phenylalanine ammonialyase (PAL) and peroxydase activity and enhances papilla autofluorescence and $\mathrm{H}_{2} \mathrm{O}_{2}$ accumulation. However, it does not affect catalase (CAT), cinnamyl alcohol dehydrogenase (CAD), LOX or oxalate oxidase (OXO) activities, and does not alter lipid peroxide levels [8]. According to the authors in [10], treatments of wheat with Milsana ${ }^{\circledR}$ enhance $\mathrm{H}_{2} \mathrm{O}_{2}$ accumulation at the fungal penetration site without any possible correlation with the activation of enzymes involved in ROS metabolism. Only LOX, involved in both ROS regulation and lipid peroxidation, showed a 26 to $32 \%$ increase $48 \mathrm{~h}$ postreatment in Milsana-infiltrated leaves. This weak effect of Milsana ${ }^{\circledR}$ on wheat lipid metabolism was confirmed at the lipid peroxydation level, which was shown to decrease in treated plants.

While HSA sprayings enhanced an increase in C18:2 levels only, HSA exhibited the most numerous and the highest effects in the wheat-powdery mildew interaction. HSA induced $\mathrm{H}_{2} \mathrm{O}_{2}$ accumulation, increases LOX activity in (i) conditions and decreases CAT activity in (ni) context [8]. 
While barley leaves treated with salicylate [77], sorbitol [89] or JA [91] accumulated C18:3, none of the 4 compounds tested induced any increase in C18:3 in wheat leaves according to our results.

\subsubsection{Free FAs and PLFAs content vary in SA-infiltrated wheat leaves}

The profile of free FAs and phospholipids FAs (PLFAs) in SA-infiltrated wheat leaves were also investigated and are presented in Table 5 and Table 6.

\begin{tabular}{|c|c|c|c|c|c|}
\hline & C16:0 & C18:0 & C18:1 & C18:2 & C18:3 \\
\hline $\begin{array}{l}\mu \mathrm{g} / \mathrm{mg} \text { dry } \\
\text { weight }\end{array}$ & $\begin{array}{l}\text { 2.38-fold } \\
\text { increase } \\
\text { (48-96hai) }\end{array}$ & $\begin{array}{c}\text { 2.36-fold increase } \\
\text { (48-96hai) }\end{array}$ & $\begin{array}{c}\text { 2-fold } \\
\text { increase } \\
\text { (48-96hai) }\end{array}$ & $\varnothing$ & $\begin{array}{l}\text { 2.74-fold } \\
\text { decrease } \\
\text { (6-96hai) }\end{array}$ \\
\hline$\%$ & $\begin{array}{l}\text { 1.4-fold } \\
\text { increase } \\
\text { (6-96hai) }\end{array}$ & $\begin{array}{c}\text { 1.47-fold increase } \\
\text { (6-96hai) }\end{array}$ & $\varnothing$ & $\varnothing$ & $\begin{array}{l}\text { 2.3-fold } \\
\text { decrease } \\
\text { (6-96hai) }\end{array}$ \\
\hline
\end{tabular}

Table 5. Variations in free FAs content and \% in SA-infiltrated leaves

\begin{tabular}{|c|c|c|c|c|c|}
\hline & C16:0 & C18:0 & C18:1 & C18:2 & C18:3 \\
\hline $\begin{array}{l}\mu \mathrm{g} / \mathrm{mg} \text { dry } \\
\text { weight }\end{array}$ & $\begin{array}{l}\text { 1.5-fold } \\
\text { increase } \\
\text { (48-72hai) }\end{array}$ & $\begin{array}{l}\text { 1.9-fold } \\
\text { increase } \\
\text { (6-96hai) }\end{array}$ & $\varnothing$ & $\begin{array}{c}\text { 2.7-fold } \\
\text { decrease } \\
\text { (72-96hai) }\end{array}$ & $\begin{array}{l}\text { 2.28-fold } \\
\text { decrease } \\
\text { (24-96hai) }\end{array}$ \\
\hline$\%$ & $\begin{array}{l}\text { 1.6-fold } \\
\text { increase } \\
\text { (48-96hai) }\end{array}$ & $\begin{array}{l}\text { 2.5-fold } \\
\text { increase } \\
\text { (24-96hai) }\end{array}$ & $\varnothing$ & $\varnothing$ & $\begin{array}{l}\text { 1.27-fold } \\
\text { decrease } \\
\text { (24-96hai) }\end{array}$ \\
\hline
\end{tabular}

Table 6. Variations in PLFAs content and \% in SA-infiltrated leaves

Upon treatment with SA, free palmitic acid (C16:0) accumulation was observed from 48 till 96 hai with an average of 2.38 fold-increase over this period and 1.4-fold increase at the qualitative level over the whole time-course experiment. Similar results were observed for the PLFAs C16:0, essentially the last 3 days of the experiment. Since monomers of cutin are synthesized C16:0, SA seems to induce the reinforcement of the plant cuticule. In A. thaliana, levels of the $\mathrm{C} 16: 3$ (hexadecatrienoic acid) increase within a few hours of exposure to an avirulent strain of $P$. syringae [92].

Increases in both classes of stearic acid C18:0 content and percentage were observed in SAinfiltrated leaves. In soybean, increased levels of C18:0 likely inhibit soybean seed colonization by the seed-borne pathogen Diaporthe phaseolorum [93].

A transient 2-fold increase in free FAs C18:1 content was recorded. A sharp and rapid increase in C18:1 level was observed in parsley cells treated with a fungal elicitor [83]. Recent studies suggest that free oleic acid (18:1) levels in the chloroplast regulate the defense response of plants to pathogens including programmed cell death and SAR [94]. 
A 2,7-fold decrease in C18:2 PLFAs was observed 72 till 96 hai of SA. In sorbitol-treated barley leaves, the accumulation of C18:2 occurred from $12 \mathrm{~h}$ till $72 \mathrm{~h}$ after treatment [89]. The development of asexual spores, and the formation of cleistothecia and sclerotia of Aspergillus spp are affected by C18:2 and light [95]. Avocado fruits infected with Colletotrichum gleosporioides spores accumulate C18:2 [96].

One of the most interesting results is the general decrease of C18:3 level after SA-infiltration. Most of the studies report increases in 18:3 levels such in suspension cells of California poppy (Eschscholtzia californica) treated with a yeast elicitor [97]. In A. thaliana, an increase of C18:3 occurred within a few hours of exposure to an avirulent strain of $P$. syringae [91]. The Arabidopsis fad7 fad8 mutant defective in the generation of C18:3 in chloroplastic membranes is deficient in ROS production following infection with avirulent strains of Pseudomonas syringae and shows enhanced susceptibility to this pathogen [92]. C18:3 stimulates NADPH oxidase activity in vitro, which suggests that C18:3 modulates ROS production and the subsequent defense responses during $R$ gene-mediated resistance in plants [92]. The Arabidopsis fad $3 \mathrm{fad} 7 \mathrm{fad} 8$ triple mutant is unable to accumulate JA because of a deficiency in C18:3 and is highly susceptible to infection by insect larvae [98]. The fad 3 fad7 fad8 mutant plants are also highly susceptible to root rot by Pythium jasmonium, and this susceptibility can be alleviated by the exogenous application of MeJA [99]. Rhizobacteria-induced enhanced resistance to Botrytis cinerea is associated with the accumulation of C18:2 and C18:3 FAs in bean [100].

In barley leaves, 13-LOX are induced by SA and jasmonates. Upon SA treatment, free C18:3 and C18:2 accumulate in a 10:1 ratio reflecting their relative occurrence in leaf tissues [78]. The release of 18:3 from plant membrane lipids by stress-activated lipases is thought to provide the substrate for lipoxygenase and subsequent octadecanoid (oxylipin) pathway synthesis of JA and methyl jasmonate [101,102]. JA and methyl jasmonate participate in the signal regulation of a number of plant processes including wound and pathogen defense responses. Efforts have been successful to identify and characterize fatty acids esterifying lipases that are activated by pathogen attack and/or environmental stress. Results suggest that both A1 and A2 phospholipases are involved in 18:3 mobilization form membrane lipids [103]. In the C4 monocotyledon sorghum (Sorghum bicolor L.), SA induced genes of the octadecanoic acid pathway for JA synthesis which resulted in higher JA content [104].

However, in tobacco tissues expressing a hypersensitive response to TMV, an increase in the saturation of fatty acids contained in the microsomal phospholipids was observed while C18:3 content decreased by $9 \%$ [105]. Interestingly, the authors credited the change of FAs composition to a four-fold increase in LOX activity of the infected tobacco tissues.

The decreases in free FAs observed with our model could be explained by a rapid dioxygenation via LOX activity. Furthermore, accumulation of C16:0 and C18:0 coupled with no significant increase in C18:1 means that elongation of C16:0 into C18:0 is not followed by desaturation into C18:1, C18:2 and finally, C18:3. Such results could explain the reduced content level of $\mathrm{C} 18: 3$. 


\subsection{Itp gene expression is induced by SA infiltration}

The effect of SA on the expression of a lipid transfer protein-encoding gene ltp was also conducted according to the same time-course experiment (figure 8). SA induced a biphasic ltp expression pattern: a 1.7-fold increase at 9hai followed by an average of 4.6-fold increase between 48 and 96hai.

The LTPs extracellular distribution in the exposed surfaces in vascular tissue systems, high abundance and corresponding genes expression in response to infection by pathogens suggest that they are active plant-defense proteins [106]. A combined expression of chitinase and LTP-encoding genes in transgenic carrot plants enhances resistance to Botrytis sp. and Alternaria sp. [107]. A high global expression of an ltp gene in resistant wheat to Tilletia tritici was identified [108]. The nonspecific nsLTP-encoding gene expression profile was evaluated in grape cells suspension in response to various defenserealted signal molecules [109]. A rapid and strong accumulation of nsLTPs mRNAs was recorded upon treatment with ergosterol ( $5 \mathrm{~h}$ after treatment with hybridation signal more than 300X A.U.) whereas JA, cholesterol and sitosterol promoted an accumulation but to a lesser extent (hybridation signal between 100 and 200X). However, SA had no effect on nsLTPs mRNAs accumulation.

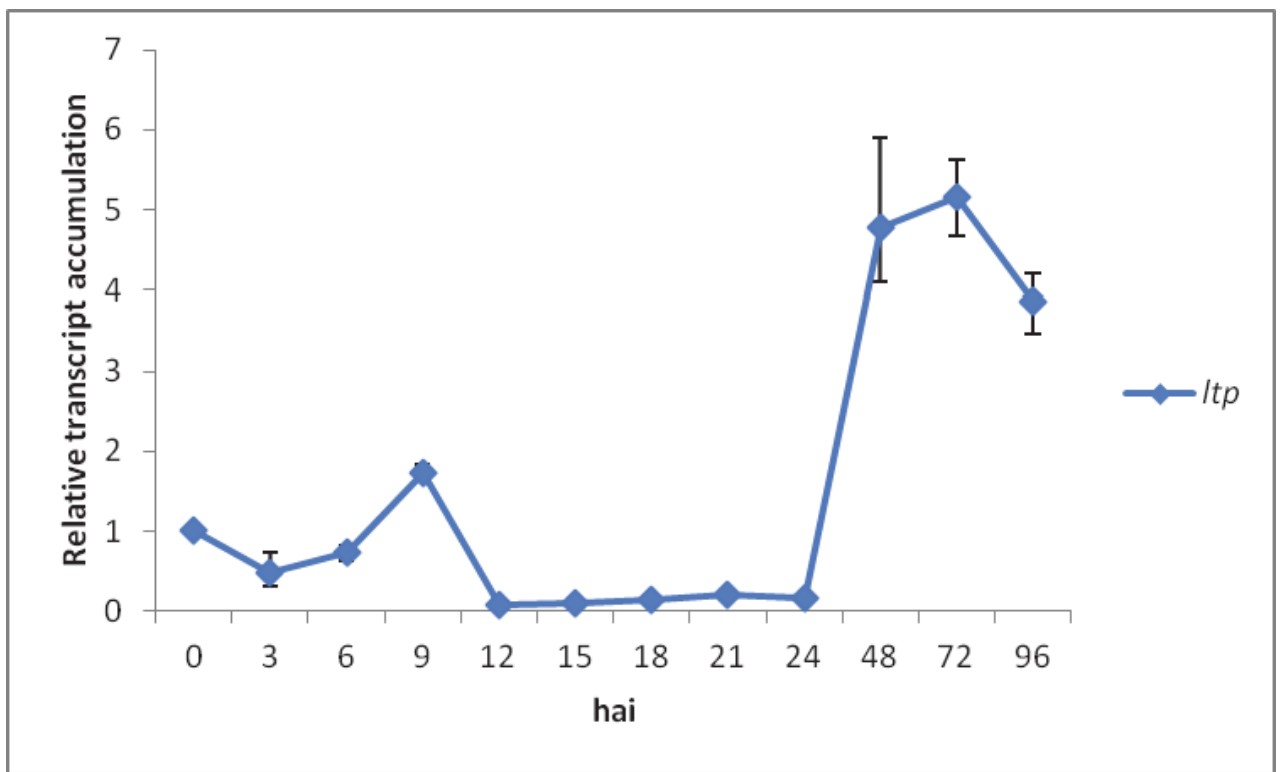

Figure 8. ltp gene expression in wheat leaves treated with SA

Moreover, LTPs are known to be differentially expressed during a pathogenic interaction because they are potentially good ligands to oleic C18:1, linoleic C18:2 and eicosadienoic acids C20:2 [110]. Among 28 identified wheat nsLTP, eight nsLTP expressed in yeast exhibited lipid binding activity [111]. These proteins could be involved in the intracellular 
traffic of phospholipids and in the transport of cutin monomers. Interestingly, SA induces the expression of the ltp gene in the same period when its impact on the lipid metabolism is the most important. One could think that the lipid transfer capacity of these binding proteins participate in the modulation of the lipid scenery upon resistance induction with SA.

\section{Conclusion}

The present chapter provides evidences for the effect of resistance inducers on wheat lipid metabolism and presents the strategy we used in order to characterize their mode of action at different levels: total FA content and relative proportion, PA, PE and DAG contents, expression of genes such as PLC and LTP-encoding ones. Lipid metabolism is therefore a marker of induced resistance in wheat. To our knowledge, such findings have never been presented before on Triticum aestivum.

Salicylic acid is very likely to induce the formation of PA through the activation of phospholipases C and/or D pathways: induction of PLC gene expression, together with DAG accumulation suggests that the PLC pathway is enhanced and leads to PA production. On the other hand, reduction of PE content suggests that PLD pathway is triggered upon SA infiltration in order to ensure PA synthesis. lox gene expression up-regulation and corresponding enzymatic activity, along with the decrease of linolenic acid content, suggests that SA modulates lipid enzymatic peroxidation. Moreover, the expression of ltp gene was induced by SA, showing the involvement of the corresponding protein in the lipid signaling metabolism.

The tested resistance inducers had some similarities in their mode of action, relatively to total FAs profiles. Trehalose and Milsana ${ }^{\circledR}$ seem to share similar modes of action via the increase of C12:0 and decrease of C20:2 contents. Iodus ${ }^{\circledR}$ exhibited the largest effects on FAs profiles, inducing increases in C12:0 and C18:1 and decreases in C20:2. HSA, however, was the only resistance inducer that modulated positively the content of C18:2.

Future investigations have to be extended to other genes expression and corresponding enzymatic activities acting downstream of lipoxygenase in order to figure out whether the LOX-derived hydroperoxides are metabolized during the JA synthesis. Furthermore, a global approach using microarrays based on wheat cDNA chips would be a useful tool for increasing our knowledge of the plant lipidome in our wheat-powdery pathosystem.

\section{Author details}

Christine Tayeh, Béatrice Randoux, Frédéric Laruelle, Natacha Bourdon, Delphine Renard-Merlier and Philippe Reignault Université du Littoral Côte d'Opale, Unité de Chimie Environnementale et Interactions sur le Vivant (UCEIV), France

" Corresponding Author 


\section{Acknowledgement}

Christine TAYEH is supported by the French Ministry of National Education and Research.

\section{References}

[1] Benhamou N. Elicitor-induced plant defense pathways. Trends in Plant Science 1996;1(7) 233-240.

[2] Walker AS, Leroux P, Bill L, Wilhelm E, Caron D. Oidium du blé: quelles résistances aux fongicides en France? Phytoma 2004;577:49-54.

[3] Walters D, Walsh D, Newton A, Lyon G. Induced resistance for plant disease controls: maximizing the efficacy of resistance elicitors. Phytopathology 2005;95:13681373.

[4] Reignault P, Walters D. Topical application of inducers for disease control. In: Walters D (ed.). Induce resistance for plants defense. Oxford, Blackwell Publishing; 2007. p179200.

[5] Randoux B, Renard-Merlier D, Mulard G, Rossard S, Duyme F, Sanssené J, Courtois J, Durand R, Reignault Ph. Distinct defenses induced in wheat against powdery mildew by acetylated and nonacteylated oligogalacturonides. Phytopathology 2010;100:13521363.

[6] Reignault Ph, Cogan A, Muchembled J, Lounes-Hadj Sahraoui A, Durand R, Sancholle M. Trehalose induces resistance to powdery mildew in wheat. New Phytologist 2001;149:519-529.

[7] Muchembled J, Lounes-Hadj Sahraoui A, Grandmoujin-Ferjani A, Sancholle M. Changes in lipid composition of Blumeria graminis f.sp. tritici conida produced on wheat leaves treated with heptanoyl salicylic acid. Phytochemistry, 2006;67(11) 11041109.

[8] Renard-Merlier D, Randoux B, Nowak E, Farcy F, Durand R, Reignault Ph. Iodus 40, salicylic acid, heptanoyl salicylic acid and trehalose exhibit different efficacies and defense targets during a wheat/powdery mildew interaction. Phytochemistry 2007;68:1156-1164.

[9] Aziz A, Poinssot B, Daire X, Adrian M, Bezier A, Lambert B, Joubert JM, Pugin A. Laminarin elicits defense responses in grapevine and induces protection against Botrytis cinerea and Plasmopara viticola. Molecular Plant-Microbe Interactions 2003;16:1118-1128.

[10] Randoux B, Renard D, Nowak E, Sanssené J, Courtois J, Durand R, Reignault P. Inhibition of Blumeria graminis f.sp. tritici germination and partial enhancement of wheat defenses by Milsana. Phytopathology 2006;96:1278-1286.

[11] Spletzer ME, Enyedi AJ. Salicylic acid induces resistance to Alternaria solani in hydroponically grown tomato. Phytopathology 1999;89:722-727 
[12] Saika R, Singh T, Kumar R, Srivastava J, Srivastava AK, Signh K, Arora DK. Role of salicylic acid in systemic resistance induced by Pseudomonas fluorescens against Fusarium oxysporum f.sp. ciceri in chickpea. Microbiological Research 2003;158:203-213.

[13] Sparla F, Rotino L, Valgimigli MC, Pupillo P, Trost P. Systemic resistance induced by benzothiadiazole in pear inoculated with the agent of fire blight (Erwinia amylovora). Scientia Horticulturae 2004;101:269-279.

[14] Galis I, Smith JL, Jameson PE. Salicylic acid- , but not cytokinin-induced, resistance to WCIMV is associated with increased expression of SA-dependent resistance genes in Phaseolus vulgaris. Journal of Plant Pathology 2004;161:459-466.

[15] Shah J. Lipids, lipases and lipid-modifying enzymes in plant disease resistance. Annual Review of Phytopathology 2005;43:229-260.

[16] Testerink C, Munnik T. Phosphatidic acid: a multifunctional stress signaling lipid in plants. Trends in Plant Science 2005;10(8) 368-375.

[17] Wang X, Devaiah SP, Zhang W, Welti R. Signaling functions of phosphatidic acid. Progress in Lipid research 2006;45:250-278.

[18] Wang X. Lipid signaling. Current Opinion in Plant Biology 2004;7:329-336.

[19] Wang X. Phospholipase D in hormonal and stress signaling. Current Opinion in Plant Biology 2002;5:408-414.

[20] Meijer HJG, Munnik T. Phospholipid-based signaling in plants. Annual Review of Plant Biology 2003;54:265-306.

[21] Viehveger K, Dordschbal B, Roos W. Elicitor-activated phospholipase A2 generates lysophosphatidylcholines that mobilize the vacuolar $\mathrm{H}^{+}$pool for $\mathrm{pH}$ signaling via the activation of $\mathrm{Na}^{+}$-dependent proton fluxes. Plant Cell 2002;14:1509-1525.

[22] Zhao J, Davis L, Verpoorte R. Elicitor signal transduction leading to production of plant secondary metabolites. Biotechnology Advances 2005;23:283-333.

[23] La Camera S, Gouzerh G, Dhondt S, Hoffmann L, Fritig B, Legrand M, Heitz T. Metabolic reprogramming in plant innate immunity: the contributions of phenylpropanoid and oxylipin pathways. Immunological Reviews 2004;198:267-284.

[24] Feussner I, Wasternack C. The lipoxygenase pathway. Annual Review of Plant Biology 2002;53:275-297.

[25] Christensen SA, Kolomiets MV. The lipid language of plant-fungal interactions. Fungal Genetics and Biology 2011;48:4-14.

[26] Bate NJ, Rothstein SJ. C6-volatiles derived from the lipoxygenase pathway induce a subset of defense-related genes. Plant Journal 1998;16:561-569.

[27] Weiler EW, Kutchan TM, Gorba T, Brodschelm W, Nieesel U, Bublitz F. The Pseudomonas phytotoxin coronatine mimics octadecanoid signalling molecules of higher plants. FEBS Letter 1994;345:9-13.

[28] Farmer EE, Almeras E, Krisnamurthy V. Jasmonates and related oxylipins in plant responses to pathogenesis and herbivory. Current Opinion in Plant Biology 2003;6:372378. 
[29] Browse J. Jasmonate passes muster: a receptor and targets for the defense hormone. Annual Review of Plant Biology 2008;60:183-205.

[30] Ryu SB. Phospholipid-derived signaling mediated by phospholipase A in plants. Trends in Plant Science 2004;9:229-235.

[31] Dhondt S, Gouzerh G, Muller A, Legrand M, Heitz T. Spatio-temporal expression of patatin-like lipid acyl hydrolases and accumulation of jasmonates in elicitor-treated tobacco leaves are not affected by endogeneous salicylic acid. Plant Journal 2002;32:749762.

[32] Dhondt S, Geoffroy P, Stelmach BA, Legrand M, Heitz T. Soluble phospholipase A2 activity is induced before oxylipin accumulation in tobacco mosaic virus-infected tobacco leaves and is contributed by patatin-like enzymes. Plant Journal 2000;23:431440.

[33] Scherer GFE, Paul RU, Holk A, Martinec J. Down-regulation by elicitors of hosphatidylcholine hydrolyzing phospholipase $C$ and up-regulation of phospholipase A in plant cells. Biochemical and Biophysical Research Communications 2002;293:766770.

[34] Routaboul JM, Fischer SF, Browse J. Trienoic fatty acids are required to maintain chloroplast function at low temperatures. Plant Physiology 2000;124:1697-1705.

[35] Yamauchi Y, Furutera A, Seki K, Toyoda Y, Tanaka K, Sugimoto Y. Malondialdehyde generated from peroxidized linolenic acid causes protein modification in heat-stressed plants. Plant Physiology and Biochemistry 2008;46:786-793.

[36] Tumlinson JH, Engelberth J. Fatty acid derived signals that induce or regulate plant defenses against herbivory. In: Schaller A. (ed.) Induced Plant Resistance to Herbivory. Amsterdam, The Netherlands, Springer; 2008. p389-407.

[37] Kachroo A, Kachroo P. Fatty acids-derived signals in plant defense. Annual Review of phytopathology 2009;47:153-176.

[38] Sossountzov L, Ruiz-Avila L, Vignols F, Jolliot A, Arondel V, Tchang F, Grosbois M, Guerbette F, Miginiac E, Delseny M. Spatial and temporal expression of a maize lipid transfer protein gene. Plant Cell 1991;3:923-933.

[39] Kader JC. Lipid-transfer proteins in plants. Annual Review of Plant Physiology and Plant Molecular Biology 1996;47:627-654.

[40] van Loon LC, van Strien EA. The families of pathogenesis-related proteins, their activities, and comparative analysis of PR-1 proteins. Physiological and Molecular Plant Pathology 1999;55:85-97.

[41] Molina A, Segura A, Garcia-Olmedo F. Lipid transfer proteins (ns-LTPs) from barley and maize leaves are potent inhibitors of bacterial and fungal plant pathogens. FEBS Letters 1993;316(2) 119-122.

[42] Regente MC, de La Canal L. Purification, characterization and antifungal properties of a lipid-transfer protein from sunflower (Helianthus annuus) seeds. Physiologia Plantarum 2001; 10:158-163. 
[43] Patkar RN, Chattoo BB. Transgenic indica rice expressing ns-LTP-like protein shows enhanced resistance to both fungal and bacterial pathogens. Molecular Breeding 2006;17:159-171.

[44] Roy-Barman S, Sautter C, Chattoo BB. Expression of the lipid transfer protein AceAMP1 in transgenic wheat enhances antifungal activity and defense responses. Transgenic Research 2006;15:435-446.

[45] Kirubakaran IS, Mubarak Begum S, Ulaganathan K, Sakthivel N. Characterization of a new antifungal lipid transfer protein from wheat. Plant Physiology and Biochemistry 2008;46:918-927.

[46] Renard-Merlier D, Laruelle F, Nowak E, Durand R, Reignault Ph. Changes in C12:0, C18:1, C18:2 and C20:2 fatty acid content in wheat leaves treated with resistance inducers and infected by powdery mildew. Plant Biology 2009;11:75-82.

[47] Pfaffl MW, Horgan GW, Dempfle L. Relative expression software tool (REST@) for group-wise comparison and statistical analysis of relative expression results in real-time PCR. Nucleic Acids Research 2002;30(9) e36.

[48] Todd JF, Paliyath, G, Thompson, JE. Characteristics of a membrane-associated lipoxygenase in tomato fruit. Plant Physiology 1990;94:1225-1232.

[49] Avdiushko SA, Ye XS, Hildebrand DF, Kuc J. Induction of lipoxygenase activity in immunized cucumber plants. Physiological and Molecular Plant Pathology 1993;42:8395.

[50] Morris K., editor Elsevier Science - Techniques of lipidology. Isolation, analysis and identification of lipids.Amsterdam, The Netherlands; 1986.

[51] Avalli A, Contarini G. Determination of phospholipids in dairy products by SPE/HPLC/ELSD. Journal Of Chromatography A 2005;1071:185-190.

[52] Zhang W, Wang C, Qin C, Wood T, Olafsdottir G, Wang X. The oleate-stimulated

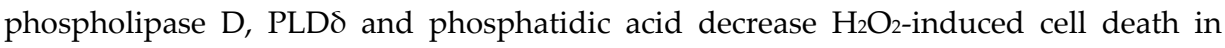
Arabidopsis. Plant Cell 2003;15:2285-2295.

[53] de Jong CF, Laxalt AM, Bargmann BOR, de Wit PJGM, Joosten MHAJ, Munnik T. Phosphatidic acid accumulation is an early response in the Cf-4/Avr4 interaction. Plant Journal 2004;39:1-12.

[54] van der Luit AH, Piatti T, van Doorn A, Musqrave A, Felix G, Boller T, Munnik T. Elicitation of suspension-cultured tomato cells triggers formation of phopshatidic acid and diacylglycerol pyrophosphate. Plant Physiology 2000;123:1507-1515.

[55] Yamaguchi T, Minami E, Shibuya N. Activation of phospholipases by $N$ acetylchitooligosaccharide elicitor in suspension-cultured rice cells mediates reactive oxygen generation. Physiologia Plantarum, 2003 1189;3:361-370.

[56] Norberg P, Liljenberg C. Lipids of plasma membranes prepared from oat root cells. Plant Physiology 1991;96:1136-1141.

[57] Sanchez JP, Chua NH. Arabidopsis PLC1 is required for secondary responses to abscisic acid signals. Plant Cell 2001;13:1143-1154. 
[58] Drøbak BK, Watkins PA. Inositol(1,4,5)trisphosphate production in plant cells: an early response to salinity and hyperosmotic stress. FEBS Letters 2000:481:240-244.

[59] Takahashi S, Katagiri T, Hirayama T, Yamaguchi-Shinozaki K, Shinozaki K. Hyperosmotic stress induces a rapid and transient increase inositol 1,4,5-trisphosphate independent of abscisic acid in Arabidopsis cell culture. Plant Cell Physiology 2001;42:214-222.

[60] Gomez-Merino FC, Brearley CA, Ornatowska M, Abdel-Haliem M, Zanor MI, MuellerRoeber B. AtDGK2, a novel diacylglycerol kinase from Arabidopsis thaliana, phosphorylates 1-stearoyl-2-arachidonoyl-sn-glycerol and 1,2-dioleoyl-sn-glycerol and exhibits cold-inducible gene expression. Journal of Biological Chemistry 2004;279:82308241.

[61] Den Hartog M, Verhoef N, Munnik T. Nod factor and elicitors activate different phospholipid signaling pathways in suspension-cultured alfalfa cells. Plant Physiology 2003;132,311-317.

[62] Lazalt AM, Raho N, ten Have A, Lamattina L. Nitric oxide is critical for inducing phosphatidic acid accumulation in xylanase-elicited tomato cells. The Journal of Biological Chemistry 2007;282(29) 21160-21168.

[63] de Torres Zabela M, Fernandez-Delmond I, Niittyla T, Sanchez P, Grant M. Differential expression of genes encoding Arabidopsis phospholipases after challenge with virulent or avirulent Pseudomonas isolates. Molecular Plant-Microbe Interactions 2002;15:808-816.

[64] Katagiri T, Takahashi S, Shinozaki K. Involvement of a novel Arabidopsis phospholipase D, AtPLDঠ in dehydration-inducible accumulation of phosphatidic acid in stress signaling. Plant Journal 2001;26:595-605.

[65] Fan L, Zheng S, Wang X. Antisense suppression of phospholipase Dठ retards abscisic acid- and ethylene-promoted senescence of postharvest Arabidopsis leaves. Plant Cell 1997;9:2183-2196.

[66] Li W, Li M, Zhang W, Welti R, Wang X. The plasma membrane-bound phospholipase

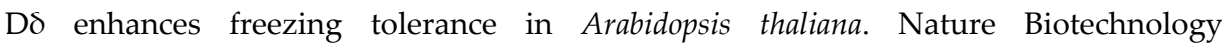
2004;22:427-433.

[67] Lee S, Suh S, Kim S, Crain, RC, Kwak JM, Nam HG, Lee Y. Systemic elevation of phosphatidic acid and lysophospholipid levels in wounded plants. Plant Journal 1997;12:547-556.

[68] Wang C, Zien CA, Afitlhile M, Weilt R, Hildebrand DF, Wang X. Involvement of phospholipase D in wound-induced accumulation of jasmonic acid in Arabidopsis. Plant Cell 2000;12:2237-2246.

[69] Farmer PK, Choi JH. Calcium and phospholipid activation of a recombinant calciumdependent protein kinase (DcCPK1) from carrot (Daucus carota L.). Biochimica and Biophysica Acta 1999;1434(1) 6-17. 
[70] Anthony RG, Henriques R, Helfer A, Mészáros t, Rios G, Testerink C, Munnik T, Deák M, Koncz C, Börge L. A protein kinase target of a PDK1 signalling pathway is involved in root hair growth in Arabidopsis. EMBO Journal 2004;23:572-581.

[71] Zhang W, Qin C, Zhao J, Wang X. Phospholipase Da1-derived phosphatidic acid interacts with ABI1 phosphatase $2 \mathrm{C}$ and regulates abscisic acid signaling. Proceedings of the National Academy of Science, USA 2004;101:9508-9513.

[72] Varnier AL, Sanchez L, Vatsa P, Boudesocque L, Garcia-Brugge A, Rabenoelina F, Sorokin A, Renault JH, Kauffman S, Pugin A, Clement C, Bailleul F, Dorey S. Bacterial rhamnolipids are novel MAMPs conferring resistance to Botrytis cinerea in grapevine. Plant, Cell and Environment 2009;32:178-193.

[73] Mauch F, Kmecl A, Schaffrath U, Volrath S, Gorlach J, Ward E, Ryals J, Dudler R. Mechanosensitive expression of a lipoxygenase gene in wheat. Plant Physiology 1997;114:1561-1566.

[74] Gorlach J, Volrath S, Knauf-Bieter G, Hengy G, Bechove U, Kogel KH, Oostendorp M, Staub T, Ward E, Kessman H, Ryals J. Benzothiadiazole, a novel class of inducers of systemic acquired resistance, activates gene expression and disease resistance in wheat. Plant Cell 1996;8:629-643.

[75] Weber H. Fatty acid-derived signals in plants. Trends in Plant Science 2002;7:217224.

[76] Vollenweider S, Weber H, Stolz S, Chételat A, Farmer EE. Fatty acid ketodienes and fatty acid ketotrienes: Michael addition acceptors that accumulate in wounded and diseased Arabidopsis leaves. Plant Journal 2000;24:467-476.

[77] Weichert H, Stenzel I, Berndt E, Wasternack C, Feussner I. Metabolic profiling of oxylipins upon salicylate treatment in barley leaves - preferential induction of the reductase pathway by salicylate. FEBS Letters 1999;464:133-137.

[78] Hause B, Vörös K, Kogel KH, Besser K, Wasternack C. A jasmonate-responsive lipoxygenase of barley leaves is induced by plant activators but not by pathogens. Journal of Plant Physiology 1999;154:459-462.

[79] Pinot F, Benveniste I, Salaün JP, Durst F. Methyl jasmonate induces lauric acid $\omega$ hydroxylase activity and accumulation of CYP94A1 transcripts but does not affect epoxide hydrolase activities in Vicia sativa seedlings. Plant Physiology 1998;118(4) 14811486.

[80] Zheng CJ, Yoo JS, Lee TG, Cho HY, Kim YH, Kim WG. Fatty acid synthesis is a target for antibacterial activity of unsaturated fatty acids. FEBS Letters 2005;579:5157-5162.

[81] Sado-Kamdem SL, Vannini L, Guerzoni ME. Effect of $\alpha$-linolenic, capric and lauric acid on the fatty acid biosynthesis in Staphylococcus aureus. International Journal of Food Microbiology 2009;129:288-294.

[82] Savchenko T, Walley J, Chehab W, Xiao Y, Kaspi R, Pye M, Mohamed M, Lazarus C, Bostock R, Dehesh K. Arachidonic Acid: en evolutionary conserved signaling molecule modulates plant stress signaling networks. The Plant Cell 2010;22:3193-3205. 
[83] Holloway PJ. The chemical constitution of plant cutins. In: Culter D. (ed). The plant cuticule. London: Linnaean Society Symposium Series; 1982. p45-85.

[84] Kirsh C, Takamiya-Wik M, Reinold S, Hahlbrock, Somssich IE. Rapid, transient, and highly localized induction of plastidial omega-3 fatty acid desaturase mRNA at fungal infection sites in Petroselinum crispum. Proceedings of the National Academy of Science, USA 1997;94:2079-2084.

[85] Kachroo P, Shanklin J, Shah J, Whittle EJ, Klessig DF. A fatty acid desaturase modulates the activation of defense signaling pathways in plants. Proceedings of the National Academy of Science, USA 2001;98 9448-9453.

[86] Kachroo A., Fu DQ, Havens W, Navarre D, Kachroo P, Ghabrial SA. An oleic acidmediated pathway induces constitutive defense signaling and enhanced resistance to multiple pathogens in soybean. Molecular Plant-Microbe Interactions 2008;21(5) 564575.

[87] Wilson RA, Calvo AM, Chang PK, Keller NP. Characterization of the Aspergillus parasiticus delta12-desaturase gene: a role for lipid metabolism in the Aspergillus-seed interaction. Microbiology 2004;150:2881-2888.

[88] Wang C, Xing J, Chin CK, Peters JS. Fatty acids with certain characteristics are potent inhibitors of germination and inducers of cell death of powdery mildew spores. Physiological and Molecular Plant Pathology 2002;61:151-161.

[89] Weichert H, Kohlmann M, Wasternack C, Freussner I. Metabolic profiling of oxylipins upon sorbitol treatment in barley leaves. Biochemical Society transactions 2000;28:861862.

[90] Vega SE, del Rio AH, Bamberg JB, Palta JP. Evidence for the up-regulation of stearoylACP (D9) desaturase gene expression during cold acclimation. American Journal of Potato Research 2004;81:125-135.

[91] Bachmann A, Hausse B, Maucher H, Garbe E, Vörös K, Weichert H, Wasternack C, Feussner I. Jasmonate induced lipid peroxidation in barley leaves initiated by distinct 13-LOX forms of choroplasts. Biological Chemistry 2002;383:1645-1657.

[92] Yaeno T, Matsuda O, Iba K. Role of cholorplast trienoic fatty acids in plant disease defense responses. Plant Journal 2004;40:931-941.

[93] Xue HQ, Upchurch RG, Kwanyuen P. Ergosterol as a quantifiable biomass marker for Diaporthe phaseolorum and Cercospora kikuchii. Plant Disease 2006;90:1395-1398.

[94] Upchurch RG. Fatty acid unsaturation, mobilization, and regulation in the response of plants to stress. Biotechnology Letters 2008;30:967-977.

[95] Calvo AM, Hinze LL, Gardner HW, Keller NP. Sporogenic effect of polyunsaturated fatty acids on development of Aspergillus spp. Applied and Environmental Microbiology 1999;65:3668-3673.

[96] Madi L,Wang X, Kobiler I, Lichter A, Prusky D. Stress on avocado fruits regulates $\Delta^{9-}$ stearoyl ACP desaturase expression, fatty acid composition, antifungal diene level and resistance to Colletotrichum gleosporiodes attack. Physiological and Molecular Plant Pathology 2009;62:277-283. 
[97] Mueller MJ, Brodschelm W, Spannagl E, Zenk MH. Signaling in the elicitation process is mediated through the octadecanoid pathway leading to jasmonic acid. Proceedings of the National Academy of Science, USA 1993;90:7490-7494.

[98] McConn M, Creelman RA, Bell E, Mullet JE, Browse J. Jasmonate is essential for insect defense in Arabidopsis. Proc. Natl. Acad Sci. USA 1997;94:5473-5477.

[99] Vijayan P, Shockey J, Levesque CA, Cook RJ, Browse J. A role for jasmonate in pathogen defense of Arabidopsis. Proc. Natl. Acad. Sci. USA 1998;95:7209-7214.

[100] Ongena M, Duby F, Rossignol F, Fauconnier ML, Dommes J, Thonart P. Stimulation of the lipoxygenase pathway is associated with systemic resistance induced in bean by a nonpathogenic Pseudomonas strain. Molecular Plant-Microbe Interactions 2004;17:10091018.

[101] Padham AK, Hopkins MT, Wang TW, McNamara LM, Lo M, Richardson LG, Smith MD, Taylor CA, Thompson JE. Characterization of a plastid triacylglycerol lipase from Arabidopsis. Plant Physiology 2007;143:1372-1384.

[102] Wasternack C. Jasmonates: an update on biosynthesis, signal transduction and action in plant stress response, growth and development. Annals of Botany 2007;100:681-697.

[103] Grechkin A. Recent developments in biochemistry of the plant lipoxygenase pathway. Progress in Lipid Research 1998;37(5) 317-352.

[104] Salzman RA, Brady JA, Finlayson SA, Buchanan CD, Summer EJ, Sun F, Klein PE, Klein RR, Pratt LH, Cordonnier-Pratt MM, Mullet JE. Transcriptional profiling of sorghum induced by methyl jasmonate, salicylic acid, and aminocyclopropane carboxylic acid reveals cooperative regulation and novel gene responses. Plant Physiology 2005;138:352-368.

[105] Ruzicska P, Gombos Z, Farkas GL. Modification of the fatty acid composition of phospholipids during the hypersensitive reaction in tobacco. Virology 1983;128:6064 .

[106] Blein JP, Coutos-Thevenot P, Marion D, Ponchet M. From elicitins to lipid transfer proteins: a new insight in cell signaling involved in plant defense mechanism. Trends in Plant Science 2002;7:293-296.

[107] Jayaraj J, Punja ZK. Combined expression of chitinase and lipid transfer protein genes in transgenic carrot plants enhances resistance to foliar fungal pathogens. Plant Cell Reports 2007;26:1539-1546.

[108] Lu ZX, Gaudet DA, Frick Puchalski B, Genswein B, Laroche A. Identification and characterization of genes differentially expressed in the resistance reaction in wheat infected with Tilletia tritici, the common bunt pathogen. Journal of Biochemistry and Molecular Biology 2005;38(4) 420-431.

[109] Gomes E, Sagot E, Gaillard C, Laquitaine L, Poinssot B, Sanejouand YH, Delrot S, Coutos-Thévenot P. Nonspecific Lipid-Transfer Protein genes expression in grape (Vitis sp.) cells in response to fungal elicitor treatments. Molecular Plant-Microbe Interactions 2003;16(5) 456-464. 
[110] Osman H, Mikes V, Milat ML, Ponchet M, Marion D, Prangé T, Maume BF, Vauthrin $\mathrm{S}$, Blein JP. Fatty acids bind to fungal elicitor cryptogein and compete with sterols. FEBS Letters 2001;489:55-58.

[111] Sun JY, Gaudet D, Lu ZX, Frick M, Puchalski B, Laroche A. Characterization and antifungal properties of wheat nonspecific lipid transfer proteins. Molecular PlantMicrobe Interactions 2008;21(3) 346-360. 